\title{
TEORI MAQASHID Syariah PERSPEKTIF IBNU ASHUR
}

\author{
Moh. Toriquddin \\ UIN Maulana Malik Ibrahim Malang \\ Telp: 085646397073 \\ email: moh.toriquddin@yahoo.com
}

\begin{abstract}
Ibnu Ashur is a contemporary figure of maqasid syariah which born in Tunisia. He was complement and continues of maqasid concept which previously created by imam al Shatibi, al Ghazali, Izzudin bin Abd. Salam, Ibnu Taymiyah, Ibnu Qayyim al Jauziyah, and another. By Ibnu Ashur, maqasid syariah easily practice in contemporary problems so that Islamic law still suitable with period or be up to date or in Arabic we can call salihun li kulli zaman wa al makan. There are few reform used by Ibnu Ashur in maqasid syariah for instance all discipline law are good characteristic is muamalah (transaction) or ibadah (religious service), all has illat (reason). For implementation maqasid theory by three steps: maqam khitab al syar'iy (situation dan condition of khitab syar'iy), al tamyiz baina al wasilah wa al maqshud (differentiate between infrastructure and purpose), istiqra' (induction). Maqasid syariah theory by Ibnu Ashur however, globallly based on maqashid al ammah and maqashid al khasah. However, foundation thought for decide maqasid using by fitrah, maslahah, and ta'lil. For knowing something that has benefit or not, he was classified it by three categories benefit for community, benefit for group or person, and realize necessary.
\end{abstract}

Ibnu Ashur adalah tokoh maqashid syariah kontemporer kelahiran Tunisia. Ia merupakan penerus sekaligus pelengkap konsep maqashid yang digagas oleh para pendahulunya seperti imam al Shatibi, al Ghazali, Izudin Bin Abd. Salam, Ibnu Taymiyah, Ibnu Qayyim al Jauziyah dan lain-lain. Di tangan Ibnu Ashur, maqashid syariah mudah untuk diterapkan pada masalah-masalah kekinian sehingga syariah Islamiyah akan selalu bisa menjawab tantangan zaman atau dengan kata lain shalihun li kulli zaman wa al makan. Ada beberapa pembaharuan yang dilakukan oleh Ibnu Ashur di bidang maqashid syariah di 
antaranya ialah semua hukum baik yang bersifat muamalah (transaksional) atau ibadah (ritual), semuanya mempunyai illat (sebab), dalam mengoperasionalkan teori maqashid ia berpegang pada tiga prinsip dasar yaitu maqam khitab al syar'iy (situasi dan kondisi khitab syar'iy), al tamyiz baina al wasilah wa al maqshud (membedakan antara prasarana dan tujuan), istiqra' (induksi). Teori maqashid syariah Ibnu Ashur secara global didasarkan padamaqasid al ammah dan maqasid al khasah, sementara dasar pemikiran dalam menetapkan maqasid dengan menggunakan fitrah, maslahah, dan ta'lil. Untuk mengetahui sesuatu itu mempunyai maslahah atau tidak, ia menggolongkan dalam tiga kelompok yaitu maslahah bagi umat, maslahah bagi kelompok atau individu, dan untuk merealisasikan kebutuhan.

Keywords: maqashid, syariah, maslahah

\section{Pendahuluan}

Secara etimologi, maqasid al Syariah merupakan istilah gabungan dari dua kata maqasid dan al Syariah. Maqasid adalah bentuk plural dari maqsud, qasd, maqsid atau qusud yang merupakan derivasi dari kata kerja qasada yaqsudu, dengan beragam makna seperti menuju suatu arah, tujuan, tengah-tengah, adil dan tidak melampaui batas, jalan lurus, tengah-tengah antara berlebihlebihan dan kekurangan (Mawardi, 2010:179). Syariah, secara etimologi bermakna jalan menuju mata air, jalan menuju mata air ini dapat pula dikatakan sebagai jalan kearah sumber pokok kehidupan. Syariah secara terminologi adalah al nusus al muqaddasah (teks-teks suci) dari al Quran dan al Sunnah yang mutawatir yang sama sekali belum dicampuri oleh pemikiran manusia. Muatan Syariah dalam arti ini mencakup aqidah, amaliyyah, dan khuluqiyyah (Bakri, 1996: 61). Secara terminologis, maqasid al Syariah dapat diartikan sebagai nilai dan makna yang dijadikan tujuan dan hendak direalisasikan oleh pembuat syariah (Allah SWT) dibalik pembuatan syariat dan hukum, yang diteliti oleh para ulama mujtahid dari teks-teks syariah (Auda, 2007: 15).

Sementara Muhammad Thohir Ibnu Ashur membagi maqasid Syariah menjadi dua dan mendefinisikan keduanya: pertama, maqasid al tashri' al ammah adalah makna-makna dan hikmah yang tersembunyi pada seluruh atau mayoritas hukum, yang mana subtansi hukum tersebut tidak terikat ruang hukum secara khusus. Kedua, maqasid al khasah adalah cara-cara yang dikehendaki shari' untuk merealisasikan kemanfaatan manusia, atau untuk menjaga kemaslahatan umum dalam amal perbuatan yang khusus (Al Raisuni, 1992: 14). 
Dari dua definisi di atas bisa ditarik kesimpulan bahwa maqasid Syariah adalah tujuan-tujuan akhir yang harus terealisasi dengan diaplikasikannya syariat. Maqasid al Syariah bisa berupa maqasid Syariah al'ammah, yang meliputi keseluruhan aspek syariat dan maqasid Syariah al khasah yang dikhususkan pada satu bab dari bab-bab syariat yang ada, seperti maqasid al Syariah pada bidang ekonomi, hukum keluarga dan lain-lain, atau maqasid Syariah al juz'iyyah yang meliputi setiap hukum shara' seperti kewajiban shalat, diharamkannya zina, dan sebagainya (Mawardi, 2010: 183).

Pada tulisan ini pembahasan akan difokuskan pada teori maqashid syariah menurut Ibnu Ashur. Dengan harapan agar bisa mengetahui karakteristik dan keunikan teori tersebut.

\section{Biografi Ibnu Ashur}

Nama lengkapnya adalah Muhammad at Thahir Ibnu Muhammad bin Muhammad at Thahir bin Muhammad bin Syekh Muhammad as Syadzili bin Abdul Qadir bin Muhammad bin Asyur . Muhammad at Tahir Ibnu Ashur dilahirkan di dekat Ibukota Tunisia pada tahun 1296 H/ 1879 M. Ibnu Ashur tumbuh dalam keluarga yang mencintai ilmu. Ia menghafal al Quran kepada Syekh Muhammad al Khiyari. Pada usia 14 tahun masuk universitas Zaitunah di Universitas ini, ia belajar tentang perlawanan terhadap sikap taqlid dan mengajak kepada pembaharuan pemikiran.

Diantara ulama besar yang pernah mendidik Ibnu Ashur adalah Syekh Ahmad bin Badr al Kafy, ia belajar dari beliau kaidah-kaidah bahasa arab, membaca dalam nahwu dan (addiry) fiqh Maliki kepada Syekh Ahmad Jamaluddin, belajar tarjamah, sastra, ilmu matematika, sejarah dan geografi kepada Syekh Salim Bawahajib. Pada Tahun 1907 M/1325 H, ketika Ibnu Ashur menjabat posisi sentral di Universitas Zaitunah, beliau gencar melontarkan ide-ide pembaharuan dalam bidang pendidikan dan memaparkannya kepada pemerintah hingga Ibnu Ashur bisa melaksanakan program-programnya. Ibnu Ashur merupakan ulama kontemporer yang sangat produktif. Di antara karyanya yang monumental abad ini adalah Maqashid as Syariah al Islamiyah (Ushul Fiqh) dan at Tahrir wa at Tanwir (Tafsir). Selain itu masih ada judul lain yaitu Ushul Nidham al Ijitima’i fil Islam (Sistem Sosial dalam Islam), Syarh al Muqaddimah al Adabiyah (Pengantar Kajian Sastra) (Suhudi, 2011, http:// fahmi-suhudi.blogspot). 


\section{Konsep Maqasid Syariah menurut Ibnu Ashur}

Pada tahap pertama Ibnu Ashur membagi maqasid syariah menjadi dua bagian yaitu maqasid al amah dan maqasid al khasah. Selanjutnya ia menguraikan dasar pemikiran dalam menetapkan maqasid yaitu dengan fitrah, maslahah, dan $t a^{\prime} l i l$. Terakhir ia menjelaskan operasionalisasi teori maqasid dengan tiga cara yaitu melalui al Maqam, Istiqra' (induksi), dan membedakan antara wasail dan maqasid. Tujuan umum (maqasid al 'amah) syariah dari seluruh hukum adalah tujuan yang tidak hanya dikhususkan pada satu hukum. Seperti tujuan dari ibadah secara umum adalah untuk mengagungkan Allah swt dan takut kepada-Nya serta tawakkal dan menyerahkan segala urusan kepadaNya. Setiap hukum baik berupa perintah maupun larangan adalah bertujuan untuk beribadah dan beragama kepada Allah, mendatangkan kemaslahatan dan menolak bahaya, memudahkan dan menghilangkan kesulitan (Habib, 2006: 224). Menjaga keteraturan umat, dan melestarikan kebaikan mereka, kebaikan ini mencakup kebaikan akal, perbuatan, dan kebaikan lingkungan sekitarnya (Muhammad Ali, 2007: 117).

Selanjutnya Ibnu Ashur membatasi maqasid al ammah dengan empat syarat yaitu pertama bersifat tetap (al thubut). Kedua, jelas (al duhur), yaitu bersifat jelas tidak menimbulkan perselisihan dalam menjelaskan arti seperti menjaga keturunan sebagai tujuan dari disyariatkannya nikah. Ketiga, terukur (indibat), yaitu suatu arti mempunyai batasan yang rinci seperti menjaga akal sebagai tujuan dishariatkannya hukuman cambuk ketika mabuk. Keempat, otentik (itrad), yaitu jika suatu tujuan shara' tidak diperdebatkan karena perbedaan daerah, etnis, dan waktu seperti tujuan kesepadanan dalam pergaulan suami istri. (Muhammad Ali, 2007: 233).

Setiap tujuan syariah secara umum bertujuan untuk kemaslahatan manusia baik di dunia maupun akhirat. Maslahat menurut istilah Ibnu Ashur adalah sifat suatu perbuatan yang dapat merealisasikan kebaikan atau kemanfaatan selamanya atau secara umum bagi orang banyak maupun individu (pribadi) (Ibnu Ashur, 2001: 235). Ibnu Ashur membagi maslahat yang menjadi maqsud (tujuan) dalam shara' menjadi empat bagian sebagai berikut:

1. Maslahat dilihat dari segi pengaruhnya bagi tegaknya umat

Dari segi ini maslahat terbagi menjadi daruriyat, hajiyat dan tahsiniyat. Maslahat daruriyat adalah masyarakat harus mendapatkan kemaslahatan ini baik secara kelompok maupun individu. Yang mana, suatu tatanan masyarakat tidak akan tegak dengan hilangnya kedaruratan itu, dan keadaan manusia akan menjadi rusak seperti binatang. Maslahat ini kembali pada kulliyat al khamsah. 
Kulliyat ini tergambar dalam penjagaan terhadap agama, jiwa, akal, harta, dan nasab (Ibnu Ashur, 2001: 80). Sedangkan maslahat al hajiyat adalah maslahat yang dibutuhkan oleh umat untuk menegakkan aturannya dengan baik, jika maslahat ini hilang tatanan kehidupan tidak menjadi rusak akan tetapi berada dalam keadaan tidak teratur. Contoh dari maslahat al hajiyat adalah menjaga kehormatan (Ibnu Ashur, 2001:84). Maslahah tahsiniyah adalah dengan maslahat itu kesempurnaan keteraturan umat dapat terealisasi. Maslahat ini merupakan sebab umat lain tertarik untuk berinteraksi dengan umat Islam. Contohnya adalah akhlak yang mulia (Ibnu Ashur, 2001: 85).

2. Maslahat dilihat dari segi hubungannya dengan umat secara umum, kelompok, atau individu

Maslahat dilihat dari segi ini terbagi menjadi dua yaitu maslahat al kulliyah, dan maslahat juz'iyah. Maslahat al kulliyah adalah maslahat yang kembali kepada umat secara umum dan kelompok besar dari suatu umat seperti penduduk suatu daerah. Contoh maslahat ini seperti menjaga kelompok dalam masyarakat dari perpecahan, dengan daruriyat, hajiyat dan tahsiniyat. Maslahat juz'iyat adalah kemaslahatan bagi individu (pribadi) atau beberapa individu, yang harus dijaga dalam hukum-hukum muamalah (Ibnu Ashur, 2001: 89-90).

3. Maslahat dilihat dari segi terealisasinya kebutuhan atau tercegahnya kerusakan

a. Maslahat qat'iyah, maslahat ini diketahui dengan adanya teks secara pasti didukung oleh teori induksi atau dengan dalil akal bahwa dalam implementasinya terdapat kebaikan yang besar atau dalam pelaksanaan hal yang sebaliknya akan terjadi bahaya yang besar, seperti membunuh orang yang enggan mengeluarkan zakat pada masa Khalifah Abi Bakr as Sidiq.

b. Maslahat Dzanniyah, yaitu maslahat yang bisa diketahui dengan persangkaan akal sehat seperti memelihara anjing untuk menjaga rumah di saat situasi mencekam, dan ada kalanya ditunjukkan oleh dalil dzanny seperti sabda Nabi SAW: La yaqdi al qadi wa huwa ghadban (seorang hakim jangan memutuskan perkara ketika ia dalam keadaan marah).

c. Maslahat Wahmiyah, adalah diandaikan terdapat kemaslahatan dan kebaikan, akan tetapi setelah dicermati kemaslahatan itu berubah menjadi kerusakan. Seperti mengkunsumsi narkoba (al Hasani, 1995: 241).

Adanya maslahat karena sebagai tujuan dari suatu perbuatan atau karena implikasi dari perbuatan. 
Maslahat semacam ini sebagai awal kemunculan metode tatollu'at (observasi), tafatanat (pemahaman), dan madahir (fenomenologi). Metode observasi adalah dengan menggunakan hilah (rekayasa), dan dzarai' (jalan menuju yang lain), metode pemahaman dengan menggunakan 'ilal (ilat-ilat hukum), metode fenomenologi adalah dengan melihat keistimewaan hukum Islam dan karakteristik keumuman serta keabadian hukum Islam (Ibnu Ashur, 2001: 91). Sifat-sifat dari maqasid Syariah menurut Ibnu Ashur kembali pada empat sifat yaitu (al Hasani, 1995: 242):

1. Arahan fitrah bagi Maqashid Syariah

Sifat dasar fitrah adalah adanya sikap toleransi, tidak adanya paksaan, ketetapan dan perubahan syariat, persamaan, kebebasan. Dengan mengacu pada fitrah maka suatu hukum akan menjadi moderat, toleran yang mengedepankan kepentingan umum, artinya mudah diterima oleh khalayak umum dan memenuhi rasa keadilan (al Hasani, 1995: 242). Mayoritas makna-makna hukum syariah khususnya hukum-hukum muamalah adalah mempunyai arti yang pasti dan jauh dari cabang, ia datang dengan redaksi umum. Karena itu maka seorang ahli fikih harus waspada bahwa hukum-hukum syariah menggunakan arti-arti terbatas sehingga kasus lain bisa diqiyaskan (dianalogikan) kepadanya. Sifat umum ini menjadikan syariah sebagai ajaran yang sesuai bagi segala waktu dan tempat (Ibnu Ashur, 2001: 122).

\section{Merealisasikan dan memuliakan Syariah}

Cara untuk merealisasikan syariah ada dua: pertama dengan cara menakut-nakuti (dengan ancaman siksa yang pedih) dan menasehati, kedua dengan cara memudahkan dan kasih sayang. Cara yang pertama dibatasi dengan beberapa cara, diantaranya: diharamkannya menyiasati hukum, menutup jalan kerusakan, membuka jalan kebaikan, dan memberikan otoritas bagi penguasa. Sedangkan cara yang kedua dibatasi dengan memudahkan dalam hukum syariah, mengalihkan hukum dari yang susah menjadi mudah, mempertimbangkan alasan mukallaf dalam meninggalkan suatu perbuatan (Ibnu Ashur, 2001: 132).

3. Kuatnya Aturan dan Ketenangan Jiwa Merupakan Tujuan Syariah

Sifat ini bisa terealisasi dengan dua cara, pertama dengan cara ijtihad dan kedua dengan adanya rukhshah.

a. Ijtihad adalah mempertimbangkan dalil-dalil shara' dan mencurahkan segala kemampuan untuk mengungkap maksud shari' (pembuat syariat). 
b. Rukhshah diberikan kepada orang yang mendapatkan kesulitan yang mengakibatkan berubahnya suatu hukum dari 'azimah menjadi rukhshah. (al Hasani, 1995: 249). Singkatnya Ibnu Ashur menetapkan maqashid 'ammah dengan membatasi empat sifat yaitu tetap (al thubut), jelas (al duhur), terukur (indhibat), dan otentik (ittirad).

Selanjutnya ia menegaskan bahwa tujuan penetapan hukum adalah untuk kemaslahatan manusia baik di dunia maupun di akhirat dalam melihat apakah suatu hukum itu mempunyai maslahat atau justru akan mendatangkan mafsadah, maka ia membatasi maslahat dari empat aspek: pertama, maslahat dilihat dari segi pengaruhnya bagi tegaknya umat terbagi menjadi dharuriyat, hajiyat dan tahsiniyat. Kedua, maslahat dilihat dari segi hubungannya dengan umat secara umum, kelompok, atau individu terbagi menjadi dua yaitu maslahat kulliyah, dan maslahat juz'iyah. Ketiga, maslahat dilihat dari segi terealisasinya kebutuhan atau tercegahnya kerusakan terbagai menjadi tiga bagian yaitu maslahat qat'iyah, maslahat danniyah, dan maslahat wahmiyah. Keempat, adanya maslahat sebagai tujuan dari suatu perbuatan atau karena implikasi dari perbuatan. Mashlahah semacam ini sebagai awal kemunculan metode tathollu'at (observasi), tafathanat (pemahaman), dan madhahir (fenomenologi).

Di samping batasan-batasan di atas Ibnu Ashur menambahkan bahwa maqashid Syariah harus sesuai dengan empat hal. Pertama, sifat dasar fitrah adalah adanya toleransi, tidak adanya paksaan, ketetapan dan perubahan syariat, persamaan dan kebebasan. Kedua memprioritaskan makna dibandingkan lafadz ketika mempertimbangkan hukum. Dengan demikian maka, syariah sebagai ajaran akan sesuai bagi segala waktu dan tempat, merealisasikan dan memulyakannya syariah.

Untuk merealisasikan syariah ada dua cara. Pertama, dengan cara menakut-nakuti dengan ancaman siksa yang pedih dan menasehati. Kedua, dengan cara memudahkan dan kasih sayang. Kuatnya aturan serta ketenangan jiwa akan bisa terealisasi dengan dua cara, pertama dengan cara ijtihad dan kedua dengan adanya rukhshah.

\section{Maqashid al Khasah (Tujuan Khusus Syariah) dalam Muamalah}

Tujuan syariah secara khusus dalam muamalah adalah cara yang dikehendaki oleh Shari' (pembuat syariat) dalam merealisasikan tujuan manusia yang bermanfaat atau untuk menjaga kemaslahatan mereka secara umum dalam perbuatan mereka secara khusus. Jika hukum ini mempunyai 
tujuan khusus, secara shara' ia akan berbeda sesuai dengan kadar implikasi hukumnya apakah ia merupakan tujuan (maqshud) atau prasarana (wasilah) (al Hasani, 1995: 250).

\section{Tingkatan Maqashid}

Maqashid terbagi menjadi dua yaitu tujuan shari' dan tujuan manusia dalam perbuatannya. Tujuan-tujuan ini diantaranya ada yang berhubungan dengan hak Allah, dengan hak hamba, gabungan antara dua hak yaitu hak Allah dan hak hamba.

\section{Hak-hak Allah}

Yang dimaksud dengan hak Allah adalah hak-hak yang menjaga tujuan umum Syariah, seperti hak baitul mal, dan hak orang yang meng-qashar, dan hak hadhanah. Hak-hak ini karena bisa mendatangkan kemanfaatan secara umum, maka dinisbatkan kepada Allah dan seseorang tidak berhak untuk menggugurkannya.

2. Hak-hak hamba

Yang dimaksud dengan hak hamba adalah perbuatan-perbuatan yang mendatangkan bagi dirinya sesuatu yang pantas atau mencegah sesuatu yang tidak pantas akan tetapi tidak mengakibatkan hilangnya maslahah secara umum ataupun mendatangkan kerusakan secara umum.

3. Percampuran antara hak Allah dan hak hamba

Contoh percampuran ini adalah qishah, qadzaf, pemerkosaan, seperti contoh di atas hak Allah SWT mendominasi secara mayoritas, dan terkadang hak hamba mendominasi, ketika tidak mungkin dibarengkan dengan hak Allah swt, seperti pengampunan dari pihak yang terbunuh terhadap pembunuhnya secara sengaja (Ibnu Ashur, 2001: 155-156)

\section{Tingkatan Wasail (Prasarana)}

Prasarana (al wasail), adalah hukum-hukum yang ditetapkan yang dengannya hukum lain bisa didapatkan, hukum ini tidak menjadi tujuan, akan tetapi untuk mendapatkan hukum lain sesuai dengan tuntutan, karena tanpa hukum ini terkadang tujuan hukum tidak tercapai atau tercapai akan tetapi terjadi kekacauan. Seperti bentuk akad dan lafadz orang-orang yang mewakafkan yang menjadikannya sebagai prasarana untuk mengetahui tujuan mereka dalam akad (Ibnu Ashur, 2001: 156).

Dengan kata lain bahwa Ibnu Ashur dalam menetapkan maqasid khasah adalah dengan cara memilah apakah suatu hukum menjadi tujuan (maqsud), 
atau menjadi prasarana (wasilah). Setelah itu ia membagi maqashid menjadi dua yaitu tujuan shari' dan tujuan manusia, dari tujuan-tujuan tersebut dilihat dari segi hubungannya dengan hak Allah dan hak hamba terbagi menjadi tiga yaitu hak-hak Allah, hak-hak hamba, percampuran antara hak Allah dan hak hamba. Sedangkan wasilah (prasarana) adalah hukum-hukum yang ditetapkan yang dengannya hukum lain bisa didapatkan, hukum ini tidak menjadi tujuan, akan tetapi untuk mendapatkan hukum lain sesuai dengan tuntutan, karena tanpa hukum ini terkadang tujuan hukum tidak tercapai atau tercapai akan tetapi terjadi kekacauan. Seperti menyaksikan dalam pernikahan dan mengumumkan nikah.

\section{Pemahaman yang Mendasari Teori Maqashid}

Ibnu Ashur mendefinisikan fitrah adalah keadaan pertama yang ada pada manusia yang tercermin pada nabi Adam AS. Ia merupakan keadaan yang bisa menerima kebaikan dan konsistensi yang merupakan maksud dari firman Allah SWT adalah manusia itu (dahulunya) satu umat. Tauhid, petunjuk, dan kebaikan adalah fitrah yang diciptakan Allah SWT ketika menciptakan manusia (al Hasani, 1995: 266).

1. Maqashid al khasah: tujuan yang paling penting yang didasarkan pada fitrah adalah tujuan menentukan hak-hak melalui penciptaan. Asal kejadian telah menimbulkan hak bersamaan terciptanya pemilik hak. Hak ini adalah hak yang paling tinggi di dunia. Ibnu Ashur menjelaskan hak-hak ini sebagai: hak manusia dalam menggunakan badan, hak terhadap apa yang telah ia lahirkan, hak terhadap sesuatu yang dilahirkan dari barang yang menjadi haknya,

2. Maqashid al 'ammah: tujuan umum yang dibangun berdasarkan fitrah adalah: bersifat umum, persamaan, kebebasan, toleransi, hilangnya paksaan (nikayah) dari Syariah dan tujuan umum Syariah (al Hasani, 1995: 273).

Ibnu Ashur menegaskan pentingnya fitrah untuk membantu ahli fiqih dalam menyimpulkan hukum, karena ukuran ini bisa dijadikan alat untuk menilai perbuatan para mukallaf. Maka sesuatu yang sangat melenceng dari fitrah, ia dianggap haram, sedangkan sesuatu yang mengakibatkan terpeliharnnya keberadaan fitrah maka ia hukumnya wajib, sedangkan sesuatu yang berada di bawah keduanya maka ia dilarang, sedangkan sesuatu yang tidak bersentuhan dengan fitrah maka ia diperbolehkan.

Terkadang sifat fitrah ini bertentangan dalam satu perbuatan, jika 
dimungkinkan untuk menggabungkan keduanya maka digabungkan, dan jika tidak mungkin maka dipilih perbuatan yang mengakibatkan terpeliharanya fitrah. Ibnu Ashur menjelaskan bahwa semua perbuatan yang disukai oleh akal sehat untuk dilakukan manusia maka ia termasuk fitrah, sedangkan sebaliknya adalah telah melenceng dari fitrah (al Hasani, 1995: 278). Alal al Fasi menjelaskan pengertian fitrah adalah setiap kemaslahatan adalah fitrah, seperti jujur, menepati janji, ikhlas, amanah, adil, lemah lembut terhadap sesama, berbuat baik, toleransi. Sebaliknya sifat dusta, khianat, menipu, ingkar janji, saling membenci, berbuat buruk, fanatik, adalah melawan fitrah (al Fasi, 1993: 194).

\section{Mendatangkan Kemaslahatan dan Menolak Mafsadah dalam Muamalat}

Ibnu Ashur mendefinisikan maslahah adalah sifat bagi perbuatan yang bisa mendatangkan kebaikan, manfaat untuk selamanya secara mayoritas maupun individu. Mashlahah dalam bidang muamalah modern, baik yang bersifat umum atau khusus (Ibnu Ashur, 2001: 68).

Mashlahah secara khusus adalah mashlahah yang bisa dirasakan manfaatnya oleh individu dengan munculnya perbuatan dari para individu untuk kepentingan masyarakat yang terdiri dari para individu. Sedangkan mashlahah secara umum didapatkan sebagai pengikut atau konsekwensi logis dari mashlahah khusus, seperti menjaga harta dari israf (berlebih-lebihan) (Ibnu Ashur, 2001: 68). Menurut Mustafa Zaid, mashlahah ditinjau dari segi dibutuhkannya terbagi menjadi tiga: mashlahah daruriyah, mashlahah hajiyah, mashlahah tahsiniyah (Zaid, 1964: 55).

Mendatangkan mashlahah dan menolak mafsadah ini sesuai dengan kaidah yang digagas oleh Shatibi adalah Wad'u al syarai' innama huwa li masalih al 'ibad fi al 'ajil wa al aajil ma'an (penentuan hukum-hukum shariat adalah untuk kemaslahatan hamba, baik untuk saat ini maupun nanti) (Al Kilani, 2000: 126).

Dasar mashlahah pada hak-hak dalam muamalat menurut Ibnu Ashur terbagi menjadi dua, hak-hak Allah sebagai mashlahah 'ammah dan hak-hak hamba sebagai mashlahah khasah. Ketika mashlahah 'ammah bisa mendatangkan kemanfaatan secara umum atau secara mayoritas atau melindungi hak orang yang tidak bisa melindungi haknya, maka Shari' mewajibkan dengan wajib 'ain, dan di sisi lain diwajibkan dengan wajib kifayah. Seperti wajibnya menjaga jiwa, yang wajib kifayah menyelamatkan orang yang tenggelam (Ibnu Ashur, 2001: 75). Sedangkan maslahat khasah adalah transaksi yang mendatangkan 
kemanfaatan untuk diri sendiri. Ketika terjadi pertentangan antara dua mashlahahmaka perlu dilakukan tarjih, seperti mendahulukan mashlahahiman dari pada mashlahah amal (Ibnu Ashur, 2001: 78).

\section{Tingkatan Mashlahah yang Dituju Secara Syara'}

Ibnu Ashur membagi mashlahah menjadi dua, pertama, mashlahah di bidang transaksi antar manusia dalam bingkai sosial. Kedua, mashlahah yang difokuskan kepada manusia secara individual. Singkatnya Ibnu Ashur mendasarkan maslahat pada dua dasar yang pertama yang ia sebut dengan dasar politik (ta'sil al siyasi) dan kedua dengan dasar penetapan hukum ( $t a$ 'sil al tashri'i) (al Hasani, 1995: 298).

a. Dasar Politik (ta'sil al siyasi)

Termasuk ke dalam tujuan shari'ah adalah adanya masyarakat Islam yang kuat, disegani, dan tenang jiwanya. Hal ini tidak akan bisa terealisasi tanpa adanya perangkat pendukung sebagai berikut:

1) Mashlahah daruriyat adalah jika hal tersebut tidak ada maka urusan umat di dunia akan kacau artinya hal itu menyebabkan terjadinya kekacauan dan dikuasainnya umat ini oleh musuh. Untuk menegakkan penjagaan ini dibutuhkan organisasi masyarakat yang diakui oleh pemerintah (organisasi legal).

2) Mashlahah haajiyah adalah mashlahah yang dengannya ketertiban umum akan bisa terealisasikan dengan baik. Jika mashlahah ini hilang tidak sampai mengakibatkan kekacauan, akan tetapi kesulitan dan kesukaran tidak bisa dihilangkan. Ibnu Ashur hanya mengkhususkan mashlahah ini dalam bidang transaksi dan pernikahan.

3) Mashlahah Tahsiniyah adalah untuk menampakkan umat Islam agar disukai oleh kelompok lain. Tugas ini diemban oleh kekuasaan politik (al Hasani, 1995: 300).

\section{Dasar Tasyri'i (ta'sil al tasyri'i)}

Tujuan dasar dari ta'sil al tasyri'i adalah ingin menunjukkan pentingnya mashlahah mursalah. Arti irsal adalah Shari' tidak menggantungkan suatu kejadian-kejadian dengan teks hukum tertentu, dan juga tidak ditemukan persamaan sehingga dapat di ilhaqkan (dipertemukan) di dalam qiyas.

Ibnu Ashur menjelaskan dasar operasional istidlal ini sebagai berikut: adanya suatu sifat yang pantas dijadikan suatu illat ia tidak didasarkan pada suatu hukum asal tertentu, akan tetapi disandarkan kepada kemaslahatan 
secara umum dalam perspektif logika. Jika persamaan (ilhaq) di dalam qiyas adalah persamaan (ilhaq) secara juz'i dengan juz'i yang lainnya yang diketahui di dalam shara' karena ada unsur kesamaan dari segi illat-nya, sebagai mashlahah juz'iyyah dzanniyyah, maka persamaan (ilhaq) pada maslahah mursalah adalah persamaan (ilhaq) juz'iyyah, yang tidak diketahui dalam hukum syara' dengan metode induksi (mustaqriah) dari dalil shara', baik induksi secara pasti ataupun secara dzanny yang mendekati kepastian (al Hasani, 1995: 301).

Ibnu Ashur menambahkan jika terjadi pertentangan antara beberapa maslahah, kemaslahatan lebih ringan dibandingkan kerusakan, maka seorang mujtahid harus mempertimbangkan pertentangan-pertentangan itu dengan hal-hal sebagai berikut:

1. Kuatnya pengaruh kemaslahatan yang diperoleh dan implikasinya baik berupa kemaslahatan atau kemafsadatan.

2. Tinggi rendahnya kemaslahatan dapat diketahui dengan cara induksi yang mana mashlahahtersebut sebagai tujuan Shari' dalam rangka untuk mendapatkan yang rajih dan mengabaikan yang marjuh.

3. Kebutuhan umum adalah untuk mendapatkan mashlahah 'ammah atau mashlahah khasah.

4. Perbedaan situasi dan kondisi suatu masyarakat dalam keadaan damai maupun perang untuk mendapatkan mashlahahataupun menolak mafsadah (Ibnu Ashur, 2001: 88).

\section{Ta'lil (mencari illat hukum)}

Ta'lil dari kata 'alla al rajulu artinya seorang laki-laki mengadu karena sakit, dikatakan: hadza 'illatun li hadza artinya ini sebab untuk ini. I'talla artinya ketika seseorang berpegang kepada suatu hujjah. Dan a'allahu menjadikan sesuatu mempunyai 'illat. Dari penggunaan kata 'allala dalam bahasa Arab berarti: mencari sebab-sebab, menggunakan hujjah-hujjah dan dalil-dalil, atau menjelaskan rahasia-rahasia (al Hasani, 1995:306).

Menurut Shatibi yang dimaksud dengan ilal (hikmah dan kemaslahatan yang dijadikan sandaran bagi suatu perintah atau kebolehan, dan kerusakan yang dijadikan sandaran dari suatu larangan). Sedangkan menurut Ibnu Ashur mencari illat merupakan dasar yang sempurna bagi pemikiran Syariah karena sesungguhnya ia bertujuan untuk menjelaskan tujuan shari' dari suatu hukum (al Hasani, 1995: 306). 


\section{Ta'lil dalam Perspektif Ibnu Ashur}

Hukum asal muamalah menurut Ibnu Ashur semuanya adalah ta'lil (berdasarkan illat). Mayoritas hukum muamalah yang dianggap sebagai hukum ta'abud (bernilai ibadah) mendatangkan kesulitan bagi kaum muslimin. Sedangkan Allah berfirman: Allah tidak menjadikan agama bagimu sebagai sesuatu yang menyulitkan (al Hasani, 1995: 318). Ibnu Ashur menjadikan ta'lil sebagai dasar teori tentang rasionalisasi pemikiran shari'ah, hal ini tampak jelas dari alasan-alasannya sebagai berikut, $t a^{\prime} l i l$ adalah salah satu kemungkinan dasar adanya qiyas ushuli (qiyas yang dilakukan oleh para ulama' ushul) dalam mencari solusi masalah-masalah yang tidak ada dalam teks, ia mencakup semua hukumhukum ibadah dan muamalah, sarana untuk menemukan karakteristik syariah, kebiasaan pencarian dalil dalam fiqih dan kebiasaan pembandingan dalam ilmu ushul fiqih. Ta'lil menurut Ibnu Ashur adalah sebagai dasar teori maqasid, karena penelitian di bidang maqashid berdasarkan pada ta'lil. Ia membangun posisinya dalam hal ta'lil ketika menafsirkan dan meneliti teks-teks syariah (al Hasani, 1995: 323). Demikian dasar-dasar umum filosofi pembentukan hukum dalam teori maqashid syariah perspektif Ibnu Ashur.

Fitrah disini memainkan peranan penting dalam membangun teori maqasid, setelah disesuakian dengan shara' baik secara pokok maupun cabang, maka setiap tujuan syariah harus berdasarkan pada fitrah yang mana dasar umumnya adalah untuk jalb al masalih dan dar'u al mafasid (mendatangkan kemaslahatan dan mencegah kerusakan), dengan demikian akan menghasilkan dalam ijtihad fiqh, rasionalisasi dalam maqashid dan istinbat hukum.

Ibnu Ashur membatasi definisi maslahah, kemudian menjelaskan tentang jalbu al masalih dan dar'u al mafasid (mendatangkan kemaslahatan dan menolak kerusakan) dalam dua bentuk yaitu batasan hak-hak dalam muamalah dan menghilangkan kontradiksi antara beberapa masalih. Selanjutnya ia menjelaskan tentang mashlahah maqsudah shar'an (kebaikan yang diinginkan oleh shara').

Mengenai ta'lil adalah salah satu metode rasionalisasi di bidang Syariah, karena ta'lil merupakan salah satu solusi untuk menjembatani "terbatas-nya" teks dan selalu berkembangnya permasalahan dalam kehidupan dan sarana untuk menemukan karakteristik aturan dan batasan hukum.

\section{Peran Maqam Pada Teori Maqashid Ibnu Ashur}

Al Maqam adalah membedakan antara teks syar'i dengan ruhnya. Pengertiannya adalah mashlahah yang diinginkan syara' yang tidak bisa dipahami dari arti asal suatu teks, akan tetapi bisa dipahami dari arti yang tersembunyi 
dari arti teks tersebut (Al Hasani, 1995: 326). Maqam adalah situasi ketika seseorang mengucapkan perkataan atau melakukan perbuatan dalam bingkai kondisi tertentu. Khitabshar'i adalah merupakan khitab bahasa yang ditransfer dari Rasul SAW, maka orang yang menjadikan dalil dengannya harus menguasai maqam (situasi)-nya agar bisa memahami arti yang dituju secara syara'.

Maqam yang dimaksud terdiri dari dua bagian. Pertama adalah maqam maqal, berupa qarinah-qarinah lafdiyah. Sedang yang kedua adalah maqam hal berupa qarinah-qarinah haliyah (situasi dan kondisi yang menyertai) situasi yang ada di saat suatu perkataan itu diucapkan (al Hasani, 1995: 339).

Tradisi teori keilmuan para Tabi'in dan Tabi'it Tabi'in berdasarkan pada pembedaan antara maqamat (situasi dan kondisi) teks-teks shari'ah seperti perjalanan ke Madinah, hal ini bertujuan untuk melihat lebih dekat pada fakta peninggalan Rasul dan perbutannya, perbuatan sahabat serta tabi'in. Dengan mengetahui maqamat (situasi dan kondisi) akan bisa menghilangkan kemungkinan-kemungkinan yang bertentangan dengan dalil dan memperjelas illat yang dituju oleh Shari' sehingga hukum-hukum yang tidak ada teksnya bisa digantungkan kepadanya.

Ibnu Ashur menjelaskan bahwa maqamat (situasi dan kondisi) yang menyebabkan perkataan dan perbuatan Rasul ada dua belas yaitu: tasyri' (pembuat hukum), fatwa, qadha' (memutuskan perkara), imarah, huda, sulh (arbitrator), isyarah 'ala al musytashir, nasihah, takmil al nufus, ta'lim al haqaiq al 'aliyah, ta'dib, tajarrud 'an al irshad. Seorang peneliti harus bisa membedakan antara maqamat (situasi dan kondisi) mauidhah, targhib, tarhib, tabshir, dan maqamat ta'lim, tahqiq, dan tasyri' (al Hasani, 1995: 350).

Maqam merupakan metode yang dipakai oleh Ibnu Ashur dalam membangun teorinya. Menurutnya maqam harus dihadirkan dalam fiqih shari'ah. Tujuan menghadirkan maqam paling tidak ada tiga tujuan; pertama, untuk mentafsirkan teks, kedua untuk mencari illat hukum dan ketiga untuk menjadikan dalil pada suatu hukum (al Hasani, 1995: 354).

\section{Arti Istiqra' dan Problem Rasionalisasi}

Secara bahasa istiqra' mempunyai arti mengamati dan meneliti. Sedangkan secara istilah adalah menarik kesimpulan dalam penelitian dari fenomena dan hukum-hukum yang bersifat parsial menuju hukum global. Kemudian memberikan hukum kelompok dengan hukum individu dan memberikan hukum komunitas dengan hukum kelompok.

Istiqra' terbagi menjadi dua yaitu naqis dan tam. Istiqra' naqis adalah 
memberikan hukum dari yang parsial ke global. Sedangkan istiqra' tam adalah memberikan hukum pada semua komponen parsial kepada hukum secara keseluruhan (al Hasani, 1995: 355).

Fungsi istiqra' dalam membangun teori maqashid Ibnu Ashur ada dua; a. memberikan tingkatan maqashid shari'ah, b. penetapan maqashid shari'ah.

1. Maqashid Shari'ah yang bersifat dzanny, hal itu bisa dicapai dengan cara induksi (istiqra') pada tasarrufat (perlakuan) shari'ah. Seperti kasus orang yang berinteraksi dengan orang-orang terhormat serta memahami apa yang ia sukai dan tidak ia sukai, kemudian dihadapkan pada pilihan antara mashlahah dan mafsadah, maka hal itu bisa deketahui dengan kebiasaannya setiap hari bahwa ia lebih memilih mashlahah dari pada mafsadah.

2. Maqshud yang dzanny yang mendekati kepastian seperti perkataan Nabi SAW. la dharar wa la dhirar.

3. Maqsud yang pasti, tingkatan ini bisa diperoleh dengan menginduksikan dalil-dalil nash al Quran seperti tujuan mempermudah: Allah tidak menjadikan agama untuk mempersulit kalian (QS al Haj: 78). Allah menghendaki kemudahan dan tidak menghendaki sesulitan bagi kalian (QS al Baqarah: 185).

Penetapan Maqashid shari'ah. Istiqra' juga bisa menetapkan maqashid hingga terjadi kesepakatan di antara ahli fiqih, para mujtahid, antara orang yang berbeda pendapat di kalangan muqallidin (Ibnu Ashur, 2001: 14).

\section{Membedakan Antara Wasilah (perantara) dan Maqshud (tujuan) dalam Fiqh Tanzil al Ahkam (fiqh kontekstual).}

Fungsi dari mengetahui wasilah al maqashid adalah untuk menjaga Syariah secara keseluruhan ketika melihat juz'iyahnya. Ketika melihat mashlahah tersebar di segala bab-bab Syariah, maka seharusnya melihat juz'iyat itu dengan kulliyat ketika hendak menerapkan dalil-dalil khusus dari kitab, sunnah, ijma' dan qiyas (Syatibi: tt: 106). Sedangkan Tujuan merealisasikan wasilah al Maqashid adalah melihat perkataan dan nash (teks) Syariah. Mayoritas ilmu ushul digambarkan dengan kaidah-kaidah lafdziyah, maka cara berdalil sangat tergantung kepada sejauh mana ahli ushul memahami maqashid al Syariah. Satu lafadz terkadang dilematis apakah ia harus diartikan secara hakiki atau majaz, umum atau khusus, ifrad atau ishtirak, secara independen atau disimpan, mutlak atau muqayyad, arti asli atau tambahan, tartib atau taqdim dan ta'khir, ta'sis (dasar) atau ta'kid, baqa' atau nasakh, arti shar'i atau aqli, urfi atau lughawi (al Hasani, 1995: 374). 
Maqashid mempunyai beberapa wasilah yang akan mengarahkan pada satu tujuan yaitu menghilangkan kontradiksi secara jelas, yang mencakup beberapa aspek seperti takhsis atau ta'mim, itlaq atau taqyid, tarjih, jam'u atau nasakh. Dengan demikian maka seorang Mujtahid tidak hanya terfokus pada satu teks shar'i akan tetapi harus melihat juga pada teks-teks lain yang terkadang memberikan gambaran global, atau menjelaskan yang mujmal, atau mentakhsis yang umum atau berakhirnya masa pengamalan suatu teks (al Hasani, 1995: 377).

Ahli Fiqih atau ahli usul fiqih dalam menetapkan illat hukum berdasarkan pada wasilahal maqashid. Hal itu dikarenakan tujuan qiyas adalah menelusuri illat illat berikut: munasabah, tanqih al manat (menyeleksi), takhrij al manat (mengeluarkan), ilgha' al fariq.

1. al Munasabah adalah suatu sifat yang tampak, terukur yang mana akal bisa memberikan hukum padanya sebagai tujuan dari terealisasinya mashlahah atau tertolaknya mafsadah.

2. Tanqih al manat adalah membuang atau tidak menganggap sebagian sifat dan menjadikan selain apa yang telah dibuang sebagai illat hukum.

3. Takhrij al manat adalah proses mengeluarkan illat nya al munasabah.

4. Ilgha' al Fariq adalah salah satu cara tanqih al manat.

Untuk seorang Mujtahid dalam mencari dalil bagi hukum-hukum yang tidak terdapat dalam qiyas dan juga tidak ada dalil secara khusus, bisa mempfokuskan pada wasilah al maqashid.

Dalam menetapkan maqashid'ammah Ibnu Ashur meringkas menjadi lima poin yaitu: pemberlakuan hukum dengan tujuan memudahkan, $d z a r i a h$, larangan mensiasati hukum, menghargai penetapan hukum, kekuatan aturan harkat martabat serta ketentraman umat. Pelaksanaan Hukum dengan Tujuan untuk Memudahkan. Untuk merealisasikan hukum-hukum Syariah secara umum tidak mungkin terjadi kecuali dengan tujuan memudahkan. Seperti contoh batasan khamr sebagai wasilah diterapkannya hukum had bagi peminumnya (Ibnu Ashur, 2001: 129).

\section{Saddu al Dzari'ah dan Fathu al Dzari'ah (Menutup dan membuka dzari'ah)}

Dzari'ah secara bahasa berarti segala sesuatu yang digunakan sebagai perantara kepada orang lain. Sedangkan dzari'ah secara istilah adalah membuka dan menutup sesuatu. Dzariah sebagaimana ia wajib di tutup ia juga wajib 
dibuka, dimakruhkan, disunahkan, dan diperbolehkan. Dzariah adalah wasilah, wasilah pada sesuatu yang diharamkan hukumnya haram, wasilah sesuatu yang wajib hukumnya wajib seperti berangkat sholat jumat dan berhaji. Dzari'ah adalah sebagai jalan mencari dalil terhadap maqashid yang akan membedakan antara wasilah dan maqsud dengan menjadikannya sebagai kerangka berfikir berdasarkan penjelasan mashlahah dan mafsadah (al Hasani, 1995: 386).

Perangkat untuk membedakan antara wasilah dan maqsud adalah bergantung pada penetapan saddu al dzari'ah sebagai tujuan umum. Tujuan ini menurut Ibnu Ashur adalah munculnya kerusakan secara umum terhadap dampak hukum di samping adanya asal kemaslahatan. Jika suatu perbuatan mengandung maslahah, namun tujuan perbuatan atau dampaknya berakibat pada mafsadah, maka dzari'ah tidak perlu ditutup. Sedangkan jika tujuan suatu perbuatan mengandung mafsadah yang bercampur maslahah maka harus dilakukan penutupan dzari'ah (Al Hasani, 1995: 390).

Tujuan Syariah melarang hilah yang menghilangkan tujuannya dari suatu hukum menurut Ibnu Ashur adalah karena hilah merupakan wasilah dengan perbuatan yang diperbolehkan secara dhahir dengan tujuan agar terbebas dari tuntutan (Ibnu Ashur, 2001: 115). Wasail al shari'ah dalam merealisasikan tujuan shari'ah kembali pada cara ekstrim dan ketat pada satu sisi dan mempermudah serta kasih sayang pada sisi yang lain, yang terdiri dari beberapa kecenderungan/insting sebagai berikut:

1. Al Wazi' al nafsani (insting kejiwaan), hal ini terealisasi dalam memperbaiki keyakinan.

2. Al Wazi' al Sultani (insting kekuasaan), seperti khalifah, Pemerintah, qadi, mufti, polisi, pengawas dan kepala Daerah.

Beberapa wasilah menggunakan jalan yang mudah dan penuh kasih sayang. Sedang Ibnu Ashur membatasi wasilah ini dengan hal-hal berikut: dasar suatu hukum bertujuan untuk memudahkan, perubahan hukum biasanya dari sulit menuju mudah, tidak mengabaikan udzur mukallaf karena berdasar pada hikmah, illat, dan batasan (Ibnu Ashur, 2001:401).

Menurut Ibnu Ashur hendaknya dalam melakukan kajian ilmiah dalam wasilah ijtihad agar selalu memperhatikan dua hal: penelitian yang bertujuan untuk menjelaskan maqashid shari' al ashliyah dan tabaiyyah, dan penelitian yang bertujuan untuk membedakan ijtihad yang bisa berubah dan tidak bisa berubah (Ibnu Ashur, 2001:151). 


\section{Menetapkan Maqashid Khashah (Tujuan Khusus)}

Pada tingkatan ini akan dijelaskan maqashid khashah (tujuan khusus) dan cara untuk merealisasikannya sebagai berikut:

1. Hak-hak bertransaksi (huquq al muamalah) penentuan dasar hak pada muamalah merupakan wasilah bagi dua tujuan peradilan: pertama pencerahan hak-hak itu pada diri qadli. Kedua menetapkan hak-hak itu pada diri orang yang berperkara. Menjaga aturan, kewibawaan, dan memperkuat persatuan umat

2. Kekuatan finansial suatu umat merupakan wasilah yang menjamin realisasi maqsud al khash (tujuan khusus).

3. Peredaran, Kejelasan, Penjagaan Merupakan Tujuan Syariah dalam Harta.

Wasilah untuk merealisasikan maqsud peredaran ada tiga wasilah pertama wasilah dalam penjagaan, kedua wasilah dalam memudahkan dan ke tiga wasilah dalam kesinambungan dan keberlangsungan (al dawam wa al tamkin) (Ibnu Ashur, 2001: 189). Pemikiran maqashid dalam teori Ibnu Ashur di samping harus memenuhi unsur maqam al khitab al shar'i untuk menjelaskan arti yang dimaksud, ia membutuhkan dua wasilah yaitu: istiqra' dan keharusan membedakan antara sesuatu yang termasuk dalam wasilah dan sesuatu yang termasuk maqashiddalam fiqih Syariah al tatbiqi. Maqam merupakan jalan untuk membatasi tujuan shar'i dari suatu khitab, sementara istiqra' (induksi) dan al tamyiz baina al wasilah wa al maqsud (membedakan antara wasilah dan tujuan) merupakan dua wasilah untuk menetapkan tujuan hukum secara khusus atau umum. Metode ini merupakan suatu teori yang berdasarkan pada filsafat pembentukan hukum, yang cara kerjanya khusus ke umum yang mana teori ini berdasarkan pada kesesuaian antara shara' dengan fitrah dan mashlahah yang berpijak pada universalitas illat-illat hukum dalam naungan fitrah dan mashlahah yang dituju oleh shara'. Syariah di bangun berdasarkan fitrah dan mashlahah hingga keduanya sesuai, hal itu merupakan teori dasar untuk mencari illat hukum dalam naungan keduanya. Mencari illat hukum berdasarkan fitrah dan mashlahah merupakan dasar filsafat teori maqashid hal ini dikarenakan antara fitrah dan mashlahah dalam Syariah berjalan beriringan.

\section{Simpulan}

Inilah teori Ibnu Ashur tentang maqashid al shar'iyyah, ia merupakan metode filsafat pembentukan hukum. Dengan metode penetapan maqashid 
Syariah-nya, terungkap bahwa ide dasar penetapan hukum Ibnu Ashur adalah berdasarkan filsafat. Dari teori induksi hukum shari'ah-nya tampak bahwa mayoritas teori ini mengacu pada dua hal: pertama, taqshid al nushus wa al ahkam (mencari tujuan teks dan hukum), kedua mencari dalil hukum-hukum tersebut.

\section{Daftar Pustaka}

Al Fasi, 'Alal. 1993. Maqashid al Syariah al Islamiyah wa Makarimuha. Ribat: Dar al Gharb al Islami.

AlHasani, Ismail. 1995. Nadzariyat al-Maqashid'Inda al Imam Muhammadal Thahir bin 'Ashur. Herdon: Al Ma’had al 'Alami li al fikr al Islami.

Al Kilani, Abd. Rahman Ibrahim. 2000. Qawaid al Maqashidi 'Inda al Imam al Shathibi 'Ardan wa Dirasatan wa Tahlilan. Dimasq: Dar al Fikr.

Al Raisuni, Ahmad. 1992. Nadhariyat al Maqashid'Inda al Imam al Shatibi, Beirut: Al Muassasat al Jam'iyat.

Al Syathibi, Imam. tt. Al Muwafaqat fi Usul al Syariah. Beirut: Dar al Kutub al 'Ilmiyyah.

Auda, Jasser. 2007. Fiqh al Maqsid Insat al Ahkm bi Maqsidih. Herndon: IIIT.

Bakri, Asafri Jaya. 1996. Konsep Maqoshid Syariah Menurut Al Syathibi. Jakarta: Pt. Raja Grafindo Persada

Habib, Muhammad Bakr Ismail. 2006. Maqashid al Islamiyah Ta'silan wa Tafilan. Makkah: Dar al Tibah al Khadra'.

Ibnu Ashur, Muhammad Tahir. 2001. Maqashidal Syariah. Yordania: Dar al Nafais.

Mawardi, Ahmad Imam. 2010. Figh Minoritas; Figh Aqalliyat dan Evolusi Maqashid al Syariah Dari Konsep ke Pendekatan. Yogyakarta: LKiS.

Muhammad 'Ali, Muhammad 'Abd. Al 'Ati. 2007. Al Maqashid al Shar' iyyah wa atharuha fi al figh al Islamiy. Kairo: Dar al Hadith.

Suhudi, Fahmi. 2011. http://fahmi-suhudi.blogspot.com/2011/10/sekilastentangibnuasyur.html. (Diakses tanggal 14 Agustus 2013).

Zaid, Mustafa. 1964. Al Mashlahah fi al Tasyri' al Islami. Kairo: Dar al Fikr. 